\title{
Utility of bone marrow aspiration in extrapulmonary tuberculosis
}

\author{
H. Singh", R. Sen ${ }^{* *}$, S. Singh ${ }^{* *}$, J.P. Malik*, S.B. Siwach*, R. Rajput ${ }^{*}$
}

\begin{abstract}
Abstrak
Dilakukan penelitian untuk memperoleh bukti tentang basil tahan asam (BTA) dalam sumsum tulang (ST) pada pasien dengan tuberkulosis ekstrapulmoner. Pada 50 kasus yang diduga tuberkulosis ekstrapulmoner dilakukan aspirasi ST dari sternum/crista iliaca dan dimasukkan dalam uji klinik pengobatan anti tuberkulosis. Hasilnya menunjukkan bahwa semua kasus yang diteliti bereaksi terhadap pengobatan anti tuberkulosis. Gambaran jangkitan penyakit adalah sebagai berikut: abdomen (20), susunan saraf pusat (19), pericard (5), limfadenopati leher (2), PUO (2), spina (1) dan milier (1). Lima puluh dua persen kasus menunjukkan BTA dalam ST (pada pewarnaan Zn), sedangkan hanya 4\% kasus yang menunjukkan BTA pada cairan tubuh lain (cairan serebro spinal/pericardium/ peritoneum). Di samping itu, perubahan sitomorfologik dari ST menunjukkan terjadinya limfositosis (22\%), peningkatan sel plasma (80\%) dan makrofag (88\%), sesuai dengan patologi infeksi yang disertai aktifitas makrofag yang berlebihan. Disimpulkan bahwa aspirasi sumsum tulang mempunyai nilai diagnostik yang definitif dan mungkin berguna apabila pemeriksaan lain belum cukup. (Med J Indones 2002; 11: 148-52)
\end{abstract}

\begin{abstract}
This study was undertaken to look for evidence of acid fast bacilli (AFB) in bone marrow (BM) in patients of extrapulmonary tuberculosis. Fifty cases suspected of extrapulmonary tuberculosis underwent bone marrow aspiration from sternum/illiac crest and were put on a therapeutic trial of antituberculosis therapy. All cases taken in the study responded to the therapy. The pattern of involvement were - abdominal (20), CNS (19), pericardial involvement (5), cervical lymphadenopathy (2), PUO (2), spinal (1) and miliary (1). 52\% cases showed evidence of AFB in BM (on Ziehl Neelsen's (ZN) staining) whereas only 4\% of cases showed evidence of AFB in any other body fluid (CSF/pericardium/peritonium). Besides this, cytomorphological changes of BM showed evidence of lymphocytosis (22\%), increased plasma cells (80\%) and prominence of macrophages (88\%), thus signifying infective pathology with macrophage overactivity. So we conclude that bone marrow aspiration has a definite diagnostic value and may prove useful when other investigations are unrewarding. (Med J Indones 2002; 11: 148-52)
\end{abstract}

Keywords: bone marrow aspiration, acid fast bacilli, extrapulmonary tuberculosis

Tuberculosis is a disease of great antiquity and hence has been described as "captain of all men of death". Its high prevalence and infectious nature makes it very essential to diagnose the disease at the earliest and treat it so as to prevent further spread in the community. $^{2}$

The diagnosis is based upon demonstration of AFB and/or cytomorphological changes characteristic of tuberculosis in the material received. Various tools for investigation available are - culture of acid fast bacilli (AFB) from secretions (including sputum), guinea pig

\footnotetext{
Department of Medicine, Pt. B.D. Sharma PGIMS, Rohtak, Haryana, India

** Department of Pathology, Pt. B.D. Sharma PGIMS, Rohtak, Haryana, India
}

innoculation, histopathology of biopsy material, and demonstration of biochemical changes along with organism identification from various affected body fluids. $^{2,3}$ Radiological investigation (roentogram ultrasound/CT scan) and serological tests (based on antibody responses) may further help in diagnosis of the disease. ${ }^{2,3}$

However all these suffer from pitfalls: (a) culture of AFB is time consuming (b) Guinea pig innoculation facility may not always be available as also it is time consuming (c) Organ involved may be inaccessible for biopsy/aspiration (d) body fluid yield is generally poor for AFB (e) radiological investigations are usually suggestive and not diagnostic and (f) serological tests are expensive, sophisticated and less specific for a developing country like ours. ${ }^{4,5}$ So diagnosis may become difficult especially when the 
lesion is extraapulmonary (that too inaccessible sites) without any apparent pulmonary lesion.

Further, during the active phase of disease, haematogenous spread of bacilli is considered an important pathway for dissemination in various organs including bone marrow. ${ }^{6,7}$ AFB has been demonstrated for variable degree of positivity in bone marrow of patients suffering from pulmonary tuberculosis. ${ }^{6,8,9}$

Hence bone marrow aspiration procedure may prove useful in demonstrating direct evidence of the active disease from easily available site in patients of extrapulmonary tuberculosis. Inspired and guided by the previous work in patients of pulmonary tuberculosis, in the present study, an attemp has been made to find the diagnostic value of bone marrow aspiration especially AFB positivity in patients of extrapulmonary tuberculosis.

\section{METHODS}

Fifty patients of suspected extrapulmonary tuberculosis admitted in medical wards of Pt. B.D. Sharma PGIMS were included in the present study. The diagnosis of extrapulmonary tuberculosis was based on: (a) detailed history (b) clinical examination (c) biochemical, haematological and radiological investigations (USG/ CT scan if required) and (d) positive response to therapeutic trial of antitubercular drugs.

In all patients (wherever possible) the affected body fluids were collected and analysed for its physical appearance, cytological/biochemical changes as well as for AFB by Ziehl Neelsen (ZN) staining.

All patients were subjected to bone marrow aspiration from sternum/illiac crest and at leas five smears were stained for $\mathrm{ZN}$ staining for looking for the presence of AFB. The slides were also stained with MGG stain and looked for cytomorphological changes (including granuloma).

Representative material (whenever possible) was sent for culture sensitivity and all patients were screened for HIV by ELISA technique.

All above probable patients were put on therapeutic trial of antitubercular drugs and the patients were followed upto three months so as to evaluate therapeutic outcome.
All data collected was subjected to standard statistical analysis.

\section{RESULTS}

Fifty consecutive patients, responding to therapeutic trial of antitubercular drugs were taken as material for the present study.

\section{Age and sex profile}

As shown in Table 1, the patients taken up for study was between 15 to 80 years of age with a mean age of $38 \pm 8.73$ years. Male : Female ratio was $3: 2$ (thirty males and twenty females).

Table 1. Sex distribution and age groups distribution

\begin{tabular}{lccc}
\hline Age in years & Male & Female & Total \\
\hline $10-20$ & 4 & 1 & 5 \\
$21-30$ & 5 & 7 & 12 \\
$31-40$ & 7 & 3 & 10 \\
$41-50$ & 5 & 3 & 8 \\
$51-60$ & 6 & 3 & 9 \\
More than 60 & 3 & 3 & 6 \\
\hline Total & 30 & 20 & 50 \\
\hline
\end{tabular}

\section{Clinical presentation profile}

The distribution of various disease site is as per table 2 .

Table 2. Distribution of site of disease

\begin{tabular}{lc}
\hline Disease site & Patients \\
\hline Abdomen & 20 \\
CNS & 19 \\
Pericardium & 5 \\
Cervical LNS (only) & 2 \\
PUO & 2 \\
Spine & 1 \\
Miliary & 1 \\
\hline
\end{tabular}

Various organs involved in abdominal tuberculosis (20) were Mesentery (13), Intestine (5), Hepatobiliary (1) and paraaortic lymphadenopathy (1). All thirteen patients of ascites had exudative fluid but were negative for AFB in the fluid.

All nineteen patients presenting meningitis, had CSF findings consistent with findings of tubercular meningitis. 
But only one patient showed evidence of AFB in CSF. The CT scan showed evidence of tuberculoma (2), minimal hydrocephalous (7) and gross hydrocephalous (2).

The five cases of pericardial effusion (including one with effusoconstrictive) revealed exudative fluid and were negative for AFB in all.

Two patients presenting as PUO (as per definition) responded to the therapeutic trial of antitubercular drug. The report of Polymerase chain reaction (PCR) received later on was also positive for tuberculosis in both.

\section{Supportive investigation}

As shown in Table 3, 38\% cases showed evidence of pulmonary involvement on routine chest roentogogram - Infiltration (32\%), calcification (4\%) and miliary pattern $(2 \%)$ cases.

Table 3. Radiological lesion, Mantoux positivity and elevated ESR distribution according to disease site

\begin{tabular}{lccc}
\hline Disease site & $\begin{array}{c}\text { Radiological } \\
\text { lung lesion }\end{array}$ & $\begin{array}{c}\text { Mantoux } \\
\text { positivity }\end{array}$ & $\begin{array}{c}\text { Elevated } \\
\text { ESR }\end{array}$ \\
\hline Abdomen (20) & 9 & 17 & 19 \\
CNS (19) & 5 & 9 & 15 \\
Pericardium (5) & 2 & 5 & 5 \\
Cervical LNS (2) & 1 & 2 & 2 \\
PUO (2) & 0 & 2 & 2 \\
Spine (1) & 1 & 0 & 1 \\
Miliary (1) & 1 & 0 & 1 \\
\hline Total (50) & $19(38 \%)$ & $35(70 \%)$ & $45(90 \%)$ \\
\hline
\end{tabular}

Thirty five patients (70\%) showed evidence of positive Mantoux reaction with twenty five $(50 \%)$ showing strongly positive reaction (more than 20 $\mathrm{mm}$ ). Abdominal tuberculosis had the highest relative positive rate i.e. $85 \%$.

Elevated Elevated Erythrocyte Sedimentation rate (by Wintrobe's method) was found in 45 patients $(90 \%)$ and it was observed that duration of symptom was directly proportional to the value of ESR.

AFB and cytomorphological pattern of bone marrow Twenty six cases (52\%) showed AFB positivity in marrow (Table 4). The cytomorphological pattern of the marrow in our study showed evidence of lymphocytosis $(22 \%)$, increased plasma cells $(80 \%)$ and prominence of macrophages (88\%). However, the granuloma was seen in only $2 \%$ cases while presence of epitheloid cells was observed in $8 \%$ and giant cells were detected in $4 \%$ cases.

Table 4. AFB positivity and cytomorphological changes in BM

\begin{tabular}{lcccc}
\hline Site & $\begin{array}{c}\text { AFB } \\
\text { positivity }\end{array}$ & $\begin{array}{c}\text { Increased } \\
\text { lymphocytes }\end{array}$ & $\begin{array}{c}\text { Increased } \\
\text { plasma } \\
\text { cells }\end{array}$ & $\begin{array}{c}\text { Prominence } \\
\text { of } \\
\text { macrophages }\end{array}$ \\
\hline $\begin{array}{l}\text { Abdomen } \\
(20)\end{array}$ & 9 & 5 & 17 & 19 \\
CNS (19) & 11 & 2 & 13 & 15 \\
$\begin{array}{l}\text { Pericardium } \\
\text { (5) }\end{array}$ & 2 & 0 & 5 & 5 \\
Cervical & 1 & 0 & 2 & 2 \\
LNS (2) & 2 & 1 & 1 & 1 \\
PUO (2) & 1 & 1 & 1 & 1 \\
Spine (1) & 0 & 0 & 1 & 1 \\
Miliary (1) & $26(52 \%)$ & $11(22 \%)$ & $40(80 \%)$ & $44(88 \%)$ \\
\hline Total (50) & & & & \\
\hline
\end{tabular}

\section{Culture and HIV testing}

The representative material (whenever possible) was sent for culture sensitivity. Culture was so done in 13 ascitic patients, 19 of meningitis, 2 of cervical lymphadenopathy and 5 cases of pericardial effusion. All of the above, except two cases of cervical lymphadenopathy, were positive for Mycobacterium tuberculosis and sensitive to primary antitubercular drugs. However cervical lymphadenopathy patients did not show growth of any organism but later did respond to antitubercular drugs given in this study.

No patient in the present series was positive for HIV on ELISA testing.

\section{DISCUSSION}

Tuberculosis continues to be a major public health problem and leading cause of morbidity and mortality in developing countries. Much of the loss caused by this disease to human race can be avoided if timely immunization, early diagnosis and adequate chemotherapy is provided to the patients. Most of the time chemotherapy is delayed due to lack of supportive laboratory investigation to establish the diagnosis. The investigation presently available may not always be rewarding and the difficulty further 
increases when the disease involves inaccessible extrapulmonary sites.

In our study, the bone marrow examination revealed AFB in $52 \%$ patients. These results are significantly higher when compared to the results of AFB in various body fluids collected in our series in cases of CNS tuberculosis. Only one patient out of nineteen showed evidence of AFB in CSF whereas none showed evidence of AFB in other fluids collected i.e. peritoneal/pericardial fluid. Other Indian studies have shown an incidence of AFB in CSF to be $10-30 \%$ whereas just $3 \%$ in peritoneal/pericardial fluid. ${ }^{10-12}$ ESR (with special relation with duration of illness) was elevated in $90 \%$ cases and Mantoux was positive in $70 \%$ of cases. In $82.8 \%$ cases with AFB positivity in marrow evidence of positive Mantoux were also found. Radiological evidence of pulmonary tuberculosis in our study was 38\% (32\% showing infiltration, $4 \%$ calcification and $2 \%$ showing miliary patterns) whereas Manohar et al have reported incidence of pulmonary radiological involvement of $30 \%$ in their series. $^{13}$

Despite a good yield of AFB i.e. 52\% patients positive for AFB, the contribution of bone marrow examination in the diagnosis of extrapulmonary tuberculosis has been reported with different results by different researchers. ${ }^{14}$ Some of the researchers have recommended an early bone marrow examination in suspected cases of tuberculosis whereas others disapprove of it. ${ }^{6,8,15,16}$ Among the various cytomorphological changes seen in marrow in our series, $22 \%$ patients showed lymphocytosis, $80 \%$ showed increase in plasma cells while $88 \%$ showed prominence of macrophages. These indicate findings of infective pathology with increased phagocytic activity in bone marrow. ${ }^{6,7}$ Presence of granuloma in bone marrow aspirate was seen in only one patients (2\%) (who also was positive for AFB in marrow) whereas broken granuloma were seen in $10 \%$ patients i.e. presence of epitheloid cells in $8 \%$ patients and giant cells in $2 \%$ patients. This finding is contrary to that as reported by Riley et al who observed that no AFB was seen in the absence of granuloma. ${ }^{17}$ This disparity could be due the fact that in bone marrow aspiration procedures, the cellular arrangements of granuloma gets crushed leading to distortion of cytomorphological appearance of bone marrow whereas in trephine biopsy the cytomorphological remains intact. The advantage of marrow aspiration for higher AFB yield is due to more amount of material from marrow aspiration as compared to trephine biopsy's.
Horowitz, Gorelick and Shafer et al have shown combined positivity of AFB between 50 to $90 \%$ in lymphnode, liver and bone marrow and have suggested that for higher yield of AFB an aspirate/ biopsy from lymphnode and liver should additionally be done. ${ }^{6,18}$ But Morris et al observed that bone marrow aspiration and trephine biopsy were of limited diagnostic value. ${ }^{19}$

Cases have been mentioned in literature where the examination of bone marrow aspirate was the only source which established the diagnosis of tuberculosis. ${ }^{17,20}$ In our present study we had two cases of pyrexia of unknown origin who had evidence of posture AFB in marrow suggesting the utility of the test in patients of pyrexia of unknown origin.

So we conclude that bone marrow examination in extrapulmonary tuberculosis has a definite diagnostic value; though it cannot be taken as a single investigation sufficient to diagnose extrapulmonary tuberculosis. However, at times this investigation has proved to be very useful especially when other investigations were unrewarding. So it is recommended that bone marrow aspiration should be done in cases of extrapulmonary tuberculosis especially in all cases where other investigations had been unrewarding and involved site is not approachable for biopsy or aspiration.

\section{REFERENCES}

1. Youmans GP. Tuberculosis ( $1^{\text {st }}$ ed.). Philadelphia: WB Saunders Company 1979; 1-7.

2. Park K. Park test book of preventive and social medicine $\left(15^{\text {th }}\right.$ ed.). Jabalpur: M/s Banarasidass Bhanot, 1997, 138-51.

3. Ravigliome MC, Narain JP, Kochi A. HIV associated tuberculosis in developing countries: clinical features, diagnosis and treatment. Bull WHO, 1992; 70:515-26.

4. Daniel TM. The rapid diagnosis of tuberculosis. A selective review. J Lab Clin Med 1990; 116:277-82.

5. Talwar GP. Continuing challenge in tuberculosis research. Ind J Tuberculosis 1992; 39:67-9.

6. Horowitz I, Gorelick DF. Tubercle bacilli in bone marrow. Am Rev Tuberculosis 1951; 63:346-55.

7. Von Lichtenberg F. Infectious disease. In: Corton RS, Kumar V, Robbin SL ed. Robbin's Pathologic basis of disease $\left(4^{\text {th }}\right.$ international edition) Philadelphia, WB Saunders 1989; 373-80.

8. Rodriguez JN, Dieguez JC, Morena MV, Aguayo DM, Vega MD, Conde $\mathrm{J}$ et al. usefulness of bone marrow examination in patients with advanced HIV infection. Rev Clin Esp 1996; 196(4):213-6. 
9. Sen R, Singh S, Singh HP, Sen J, Yadav MS, Arora BR. Demonstration of acid fast bacilli in buffy coat and bone marrow smear - a diagnostic tool in pulmonary tuberculosis. J Ind Med Assoc 1996; 94(1):379-80.

10. Aguado JM, Pons F, Casafont F. Tuberculous peritonitis. A study comparing cirrhotic and noncirrhotic patients. J Clin Gastroenterol 1990; 80:550-4.

11. VenKateswarlu K. Tuberculosis in CNS. In: Sri SS eds. Textbook of pulmonary and extrapulmonary tuberculosis. $2^{\text {nd }}$ ed. New Delhi: Interprint 1995; 221-30.

12. Tandon PN. Tuberculosis of Central Nervous System. In: Sainani SS eds. API textbook of medicine $\left(5^{\text {th }}\right.$ ed.) Bombay: Association of Physicians of India 1994; 853-6.

13. Monahar A, Simjee AE, Haffejee A, Pettengell KE. Symptoms and investigative findings in 145 patients with tuberculous peritonitis diagnosed by peritoneoscopy and biopsy over a five year period. Gut 1990; 31:1130-2.

14. Leibinger F, Guerin JM. When should we perform bone marrow biopsy in patient with miliary tuberculosis? (Letter, Comment). Chest 1995; 108(1):291-3.

15. Ribattu P, Gindre D, Kofman J, Perrin FM. Acute disseminated tuberculosis with pancytopaenia and a favourable outcome. Rev Pneumol Clin 1985; 41(1):65-8.
16. Moreno S, Hermida JM, Buzon L, Parras F, Fortun J, Bouza E. Tuberculosis presenting as diffuse pulmonary infiltrates in AIDS patients: diagnostic performance of clinical samples. Enferm Infec Microbiol Clin 1995; 13(5):297-300.

17. Riley UB, Crawford S, Barret SP, Abdalla SH. Detection of mycobacteria in bone marrow biopsy specimens taken to investigate pyrexia of unknown origin. J Clin Pathol 1995; 48(8): 706-9.

18. Shafer RW, Kim DS, Weiss JP, Quale JM. Extrapulmonary tuberculosis in patients with human immunodeficiency virus infection. Medicine (Baltimore) 1991; 70(6):384-97.

19. Morris CD, Bird AR, Nell H. The haematological and biochemical changes in severe pulmonary tuberculosis. QJ Med 1989; 73(272):1151-9.

20. Miralles P, Moreno S, Perez-Tasc on M, Cos InJ, Diaz MD, Bouza E. Fever of uncertain origin in patients infected with human immunodeficiency virus. Clin Infect Dis $1995 ; 20(4): 872-5$. 